\title{
AGRICULTURE IN DECLINE
}

\author{
Vikash Raj Satyal, Ph.D.*
}

\begin{abstract}
Despite decade long prioritized investment and planning the agriculture sector in Nepal is continuously declining in terms of production and labour engagement. If such structural shift were systematic it would be satisfactory. But in absence of sustainable development in other sectors like service and industry, such shift could be suicidal for a country having deep-rooted life style, culture, religion and knowledge based on agriculture. This paper attempts to explore the existing disappointments in agriculture, analyses some causes of the problem and will suggest some easily applicable recommendations.
\end{abstract}

Key words: agriculture, absence of sustainable development, service and industry, decline, Nepal

\section{THE CONTEXT}

Until recently Nepal was considered an 'Agriculture Country' with overwhelming proportion of its population involved in agriculture. It was a food exporting country a decade ago but now we are a food importing country. However, coming to the current time the country has shown dramatic change. In 2008/09 we imported from India paddy worth Rs. 1134.2 million and vegetable worth Rs. 1015.2 million (Economic Survey, 2010). Country has shown drastic change in the structure of employment and GDP composition in the last few years. The proportion of population depending on agriculture has sharply declined along with its share in GDP. The share of agriculture in GDP has decreased from $69 \%$ in $1974 / 75$ to $31 \%$ in 2009/2010(Table A1, Diagram 1). Also, the proportion of economically active population engaged in agriculture has shown a sharp decline from $94 \%$ in the census of 1971 to $60 \%$ in 2001(Table A2, Diagram 2).

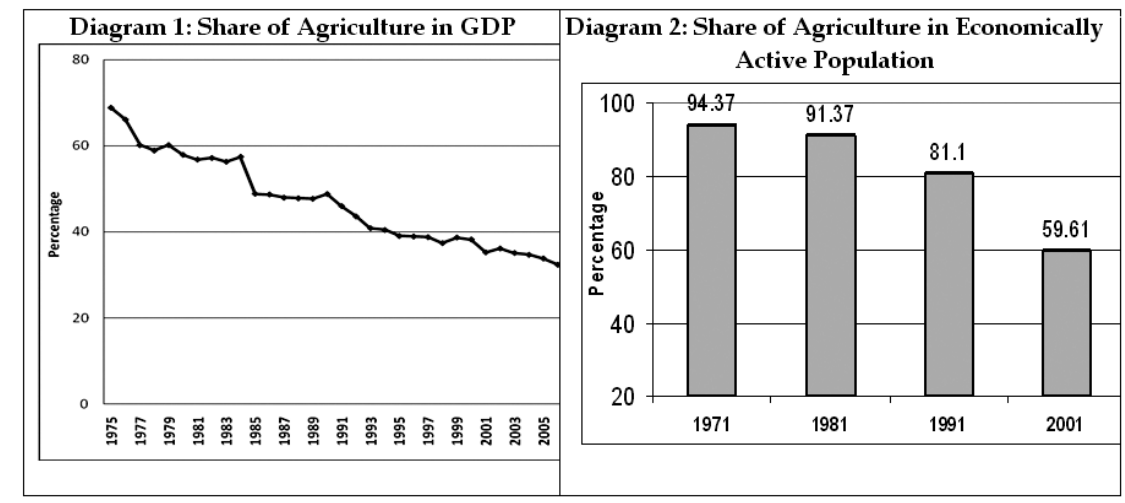

${ }^{*}$ Mr. Satyal is Associate Professor at the Department of Statistics, Amrit Campus, Tribhuvan University 
Agriculture was the primary life sustaining activity of the country from early history. It has been deep-rooted in the tradition, life practice, literature, religion, knowledge and philosophy of people. A sudden decline or shift from it could dramatically affect on all aspect of social life and national economy. This paper will try to identify some root causes behind the decline in agriculture and will try to suggest some easy-toapply recommendations for utilizing its existing potentials.

Discussion To identify major characteristic of agriculture based activities in Nepal somehypotheses given below were tested.

\section{Hypothesis 1: Agriculture is a rural phenomena}

According to 2001 census, $86 \%$ of the total population live in rural area and among the usually active labour force dwelling in rural area about two third (66\%) are mainly engrossed in agricultural activities while it was only about one third (38\%) in urban (Table 1). Also, NLFS 2008 shows that $90 \%$ of the households operating agriculture lands were in rural compared to only 10\% in urban (Table-, NLFS, 2008: 40). This shows that rural population at large represents agriculture based population. Hence, we can use rural population as a proxy for the agriculture based population whenever exact population of this type is unavailable.

Table 1: Distribution of Economically Active Population

\begin{tabular}{|c|c|c|c|}
\hline Groups & $\begin{array}{c}\text { No. Of } \\
\text { Households (hh } \\
\text { in '000) }\end{array}$ & $\%$ hh & $\begin{array}{c}\text { \% of economically active population group } \\
\text { over economically active population of that } \\
\text { group** }\end{array}$ \\
\hline Nepal & 3607 & 100 & 59.61 \\
\hline Rural & 3343 & 90.1 & 65.58 \\
\hline Urban & 263 & 9.9 & 38.16 \\
\hline
\end{tabular}

Source: ${ }^{*}$ NLFS, 2008; ** Population Monograph, 2003

\section{Hypothesis 2: Poorest population are involved in agriculture}

According to Nepal Living Standard Survey(NLSS) 2004, among the employed workforce, $71 \%$ household were depending on agriculture (self employed or getting wage from agriculture) and of the 'poorest $20 \%$ consumption group' $81 \%$ were getting employment in agriculture whereas of the richest $20 \%$ population about $50 \%$ were involved in agriculture (Table A3, Diagram 3; NLSS 2004: 52). This indicates that although a large proportion of households still depend on agriculture for their earning, 
extremely large proportion of employed engaged in agriculture are the poorest population. By income composition, the poorest quintile population were getting $62 \%$ income from agriculture compared to $25 \%$ of the richest quintile who were getting income from agriculture. One can ask to what extent is the current income from farm is sufficient for their livelihood? NLSS 2004 has shown the median per capita annual income of Rs 22 and Rs 9 thousand for urban and rural population respectively. That is the annual per capita income in US\$ was about \$57 and \$578 respectably for rural and urban population. Also regarding the adequacy of income for livelihood $70 \%$ in rural indicated their income inadequate compared to $50 \%$ of the urban (Diagram 3 ). Thus, literally we see that agriculture is synonymous for poverty and deprivation in Nepal. It shows the multidirectional correlation between poverty and farm activity,

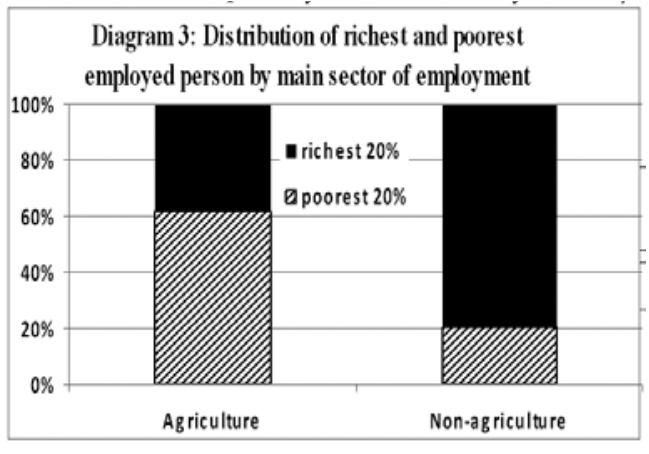
that is, poor are the farmers and dependency on farming is to plunge to poverty.

NLSS 2004, reports that in rural area population under poverty line was about $35 \%$ and in urban it was about $10 \%$. Comparing the decline in poverty headcount, between 1996 to 2004 urban area has shown a decline in poverty of $56 \%$ while it was only $20 \%$ for the rural area. This figure shows a large inequality in poverty levels in these two areas.

Now if we look at the extent of dependency of household in farm activities NLSS 2004 , shows that $55 \%$ of the rural household depends on farm activities compared to 13\% of the urban household (NLSS 2004 Vol II: 39). It shows that even the current time despite the blink future associated with agriculture the dependency of rural population on farm is enough high. It is a 'Compulsion Factor' for the rural population who have got no better alternative activities than agriculture.

\section{Hypothesis 3: Farmers are least educated household with lowest HDI}

NLFS 2008 shows the urban-rural gap in literacy level. We can found that about 72\% in rural and $86 \%$ in urban are literate. However, $51 \%$ in rural never attended school compared to $25 \%$ in urban. Also, those who got above SLC education were $1 \%$ in rural compare to $8 \%$ in urban (NLFS, 2008: 48).

Also, if we look at some human development indicators we can find that the urban rural gap is very wide. For example in 2001, rural HDI was 0.452 and urban HDI was 0.581 . When compared with the national HDI of 0.471 as reference urban HDI was 23.3 points above the national value whereas rural HDI was 4.2 points below the national value. This shows a large discrepancy in human development indicators in the two regions (Table 2). 
Table 2: Human Development Index, 2001

\begin{tabular}{|c|c|c|c|c|c|c|}
\hline Region & $\begin{array}{c}\text { Life } \\
\text { expectancy }\end{array}$ & $\begin{array}{c}\text { Adult } \\
\text { literacy }\end{array}$ & $\begin{array}{c}\text { Mean } \\
\text { year of } \\
\text { schooling }\end{array}$ & $\begin{array}{c}\text { GDP per capita } \\
\text { (ppp US\$) }\end{array}$ & HDI & $\begin{array}{c}\text { Ratio to } \\
\text { National HDI }\end{array}$ \\
\hline Nepal & 60.98 & 48.6 & 2.75 & 1310 & 0.471 & 100.0 \\
\hline Rural & 60.61 & 45.0 & 2.35 & 1162 & 0.452 & 95.8 \\
\hline Urban & 64.53 & 68.3 & 5.06 & 2224 & 0.581 & 123.3 \\
\hline
\end{tabular}

Source: Nepal Human Development Report, UNDP, 2003

Hypothesis 4: Agriculture based population are at the verge of occupational shift to non-agriculture. The 2001 census shows that $65.7 \%$ of the population were generally active in agriculture but only $59.6 \%$ claimed agriculture as their usually active occupation (active more than 6 months). This difference shows a gap of about 641 thousand people who were claiming that agriculture is only a secondary or side-job for them. In 1991, this proportion was $81.2 \%$ and $81.1 \%$ making a difference of 19 thousand (Population Monograph of Nepal, Vol II: 354- 360). We can classify them as 'farmers by birth but having alternative occupation for livelihood'. It seems that this population is not getting sufficient earning from agriculture so that they will most likely shift to other employment sector like services or industry.

Agriculture activity is basically a rural activity which is mostly carried by the poorest people of the country and these people are less educated, have very little technical know-how and lack access of information. As a large majority of people live in rural area this imply the above conditions are responsible for poverty vis-a-vis inefficient agriculture practice. From the above analysis of data and after testing of hypothesises we arrived at the following synthesized findings:

i. Agriculture based population is declining and the rate of decline was observed sharply in the last decade

ii. A large majority of population in the country still depends on agriculture for their livelihood

iii. Agriculture is principal occupation of the rural population

iv. There are a sizeable population that are engaged only partially in agricultural activities

v. Agriculture dependent population are the poorest population

vi. Agriculture dependent population are least educated and have least HDI value

\section{CAUSES OF DECLINE}

A basic question can be asked why there is such decline in agriculture in terms of employment and production. Following are some explanation. 
Decline is due to low efficiency in agriculture: The efficiency of agriculture can be defined by the inputs provided to it and output generated from it. If efficiency is low large inputs can generate small output. The agriculture sector of Nepal demonstrates less efficiency. To measure the efficiency we can select one of the basic production functions, the Cobb-Douglas production function. Here, the model $Y=e^{\gamma} L^{\alpha} I^{\beta} e^{u}$ is used. Assuming the line of regression is passing through origin and we take log function on both sides to make it linear gives as,

$\log (\mathrm{Y})=\gamma+\alpha \log (\mathrm{L})+\beta \log (\mathrm{I})+\mathrm{u}-------$

where $\mathrm{Y}$ is output, $\mathrm{L}$ is labour input, $\mathrm{I}$ is Investment and $\mathrm{u}$ random error. Also due to data constraints, some proxy variables will be used to calculate the performance of agriculture sector such as using output, $Y=$ growth rate of agriculture GDP(real based on 2000/01 price, R_GDP), L = growth rate of agriculture labour(R_EMP), and I = growth rate of agriculture investment(R_INVEST). After taking log we convert the equation to linear so that the coefficients will represent partial elasticity of output with respect to labour and capital inputs.

The result from regression using Nepali data for the year 1975/76 to 2008/09 is shown in Table 3. The correlogram of residuals is shown at the Appendix (Table A6). Results from regression can be considered satisfactory with significant $t$-values (at $7 \%)$ and residual tests.

Table 3: Regression Output: Production Function

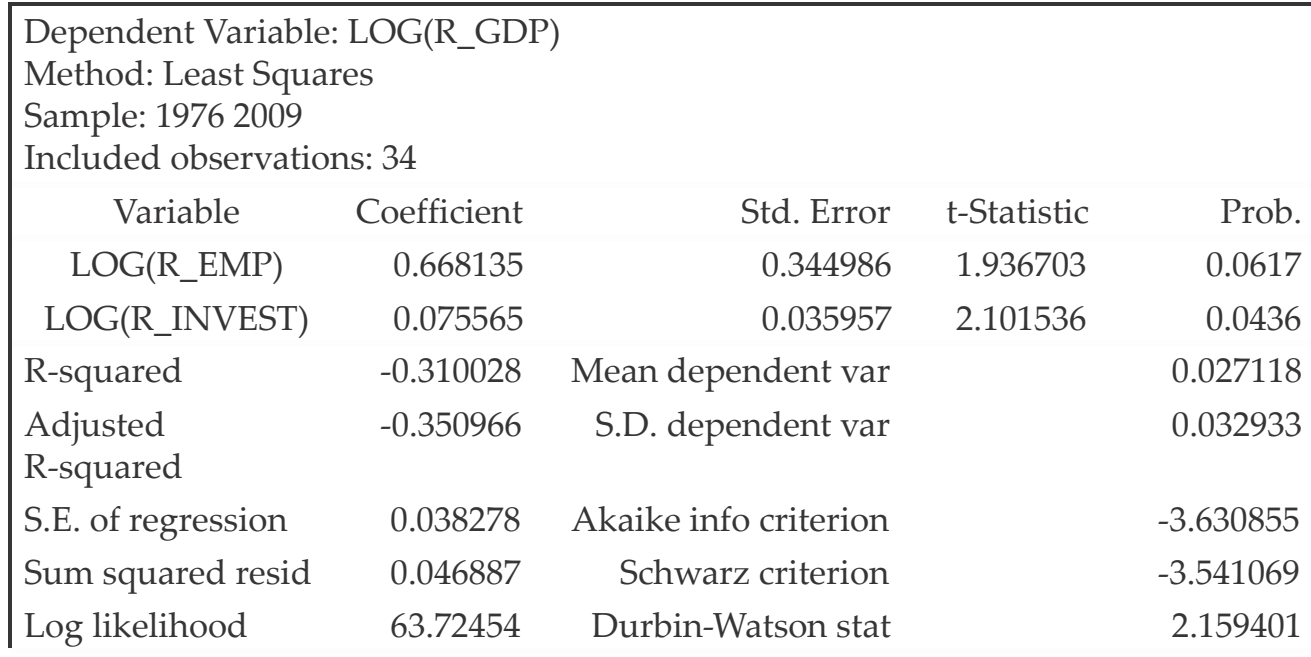

The regression analysis gives,

$$
\log (\mathrm{Y})=0.668 \log (\mathrm{L})+0.0756 \log (\mathrm{I}) .
$$


Considering the 'return to scale' of the coefficients, if $\alpha+\beta=1$ the system is called balanced and if $\alpha+\beta<1$ system is less efficient or 'diminishing return to scale'. In our case, $\alpha+\beta=0.668+0.0756=0.7436$ indicates a diminishing return to scale.

Also, the partial elasticity $\alpha=\frac{\partial \log Y}{\partial \log L}=0.668$, and $\beta=\frac{\partial \log Y}{\partial \log I}=0.0756$.

The above analysis indicates the following,

- The output from agriculture is less efficient for inputs. For example, for every 100 units of inputs (agriculture investment and agriculture labour) we can expect only 74.36 units of output (GDP contribution from agriculture). Or more specifically, if Rs 100 is spend for employment generation and Rs 100 for agriculture investment the agriculture GDP will be increased by only Rs 74.36.

- Role of employment in production is very high compared to the role of investment. This may be because the investment is very low and agriculture is basically labour intensive.

This low efficiency found here will answer why labours are shifting from the less productive sector of agriculture to other more productive sectors. For more efficient agriculture more inputs in the form of improved seed, improved tools, availability of manure, facility of irrigation is needed. To improve the labour output in agriculture upgrading the knowledge of farmers is necessary.

Rural agriculture labours are trapped highly from urbanization: Inter-country migration was the most important characteristic of rural migration in Nepal especially in the past three decades that is from 1971 onwards. Early internal migrants were in search of more fertile land to expand their farming domain. But the late chronologies of migration associate it with a search for a secured life that provides a sustainable earning and better health and educational opportunities. This altered desire of the migrants is responsible for the outrageous urbanisation in the country. In 2001 the interzonal lifetime migration was about 9\% of the total population (Population Monograph 2003: 136-142). The report shows that, of the total internal migration, rural-to-rural migration was the largest stream that accounts to $68 \%$ followed by rural-to-urban migration which was $26 \%$. The stream of rural-to-rural emigrants represents the less educated, less conversant and less empowered population that cannot take risk and challenges of the urbane lifestyle. This has caused two distinct pattern of migration. Primarily, the willing-to-migrate rural population cluster around a nearby better rural area where the life style was not very different from their original. This developed small rural agglomeration or rural hubs. Secondly, from such hubs people steps to urban area as cheap labour and contribute to urban poverty. The past trend of the 
development of urban centers which were 'high in number but small in population' is the result of this stepwise urbanization. However, this shift has contributed in the decline of agriculture as the migrants have modified their occupation.

Decline is due to out-of-country migration of rural population: Although agriculture is a rural phenomena statistics shows that most of the rural working age population are displaced creating a vacuum of agriculture labour that has highly affected its productivity. If we look at the age of migrants we can find in NLFS 2008, that out of the total $15 \%$ absentees population of the country about 80 were of age 15-44 in total and $89 \%$ were migrated from rural area. This shows that the working age population were migrating in outsize and most of them were from rural area. Also, if we look at the destination of the migrants we can find that about $50 \%$ rural migrants have crossed the national boarder for employment (Table 4). This figure from NLFS 2008, when adjusted for the total population corresponds to 1710 thousand rural population that have migrated outside Nepal.

Table 4: Final Destination of Absentee Population

(in thousand)

\begin{tabular}{|c|c|c|c|c|}
\hline & In Nepal & Outside Nepal & Do not know & Total \\
\hline Total & $1810\left(47.8^{*}\right)$ & $1933\left(51.1^{*}\right)$ & $42\left(1.1^{*}\right)$ & $3785(100.0 \%)$ \\
\hline Urban & $177\left(42.6^{*}\right)$ & $232\left(55.9^{*}\right)$ & $6\left(1.5^{*}\right)$ & $415(10.9 \%)$ \\
\hline Rural & $1633\left(48.4^{*}\right)$ & $1701\left(50.5^{*}\right)$ & $37\left(1.1^{*}\right)$ & $3371(89.1 \%)$ \\
\hline
\end{tabular}

Note: ${ }^{*}$ Row percentage in brackets. Source: NLFS, p162, CBS, 2008

\section{AGRICULTURE PLAN AND ITS REALITY}

From the first scientific Five-Year-Plan of (1956-61), agriculture was considered one of the prioritised areas. The first Five-Year-Plan considered agriculture at its second priority area with about $20 \%$ of the budget expenditures on it. The sixth, eighth and ninth Five-Year-Plan has also kept agriculture on its top priority and had envied the agriculture growth rate to become as high as $5 \%$ from the existing $3 \%$. Agriculture was prioritized intending to play an pioneering role in production, food security and employment generation, Emphasis were given for the promotion of technology in accordance with geographic conditions infrastructure development, commercialization, land management, timely delivery of inputs, expansion of irrigation, and easy access of credit. Despite these high priorities this sector has not been able to achieve desired outcomes (Economic Survey, 1999: 44). Agriculture growth was intended to be the anchor of the broad-based economic growth strategy and with this goal a 20-year long Agriculture Perspective Plan (APP) is under implementation since 1997 that will last until 2017. APP aims at reaching the majority of the population thereby stressing on broad-based growth. For example, the priority inputs - fertilizer, irrigation, rural roads and extension services - are meant to reach all farmers, small, medium and 
large. In addition, APP has taken steps to ensure that the benefits will also reach the poorest of the poor and disadvantaged groups, by emphasizing the role of community organizations, NGOs and private sector in community and leasehold forestry, formation of water user groups, promotion of farmers' cooperatives, etc. and by advancing the participation of women and other disadvantaged groups.

Despite decade long emphasis on agriculture the existing reality shows a failure of planning. The sector has shown decline in productivity and employment. The country which was a food exporting for decade had become a food importing country indicating that plans were unrealistic and with weak implementation. As found from different studies - the technology and tools we are using are almost traditional, irrigation depends on rain-water, market accessibility are very poor, storage system for the normal years are inefficient and the incidental food security for unpredictable calamities like flood, draught, terror, market failure are lacking. The agglomeration of all these conditions has made the life of farmer 'unsecured and full of inadequacies'.

\section{A Short Scenario of Agriculture for the Next Decade}

Assuming that same level of decline in agriculture will continues, a scenario is presented below for the year 2020. Using geometric extrapolation of 1975-2009 data the following simulation was made using EVIEWS. A more detailed table is shown in Annex (Table A5). Below is presented a short scenario for the year 2009 compared to year 2020.

> Share of agriculture in GDP will shrink from $30 \%$ to $24 \%$

> Share of economically active population will shrink from $60 \%$ to $20 \%$

Unemployed labour force will increase from 253 thousand to 404 thousand

\section{RECOMMENDATIONS}

A proper shift in occupation composition from agriculture to non-agriculture generally shows progress of the country. Many developed and industrialist countries have a long history of being an agriculture country in the past such as Australia, New Zealand, Holland, Denmark. So the shift in occupational demography should not pose problems provided it is a step of the evolutionary phase and that the country has developed sustainable technology. But in Nepal it is seen that this shift is rather haphazard and the occupational shift is done because of the scepticism from the blink future of agriculture. We have no adequate infrastructure for industrialization. There is no encouraging investment environment, no technological advancement that comes with applied research supported by academic research. One of the supportive conditions for Nepal seems the transit between two Frankenstein large markets of India and China. But whether we can utilize these opportunities in absence of proper future planning such as development of north-south transportation routs, warehouses, electricity as fuel for efficient transportation is a big question. 
In reality we are not able to make large investment for infrastructural development or for modern technology. However, we can still utilize its inherent knowledge and geographical diversities for a sustainable development with minimum investment and knowledge. The followings could become possible least cost sustainable alternatives for the future development of Nepal.

Agro-industry: Nepali has ample knowledge of traditional agriculture that provides supporting ability for agro-based industries. Agro-based industries needs small investment and little technological know-how but will provide more income and uses the primary agriculture outputs. Thus they are more suitable and income generating. Such industries include:

i. Preservative industries - such as tea, herbs, honey, seeds and mineral water that needs just packing and little processing.

ii. Semi-processed industries - such as vegetable oils, pickle, Jam, Jelly and squash that needs simple processing and basic know-how.

iii. Refining industries- such as carpet, dyes, paper, canned foods and whisky that needs a little advance processing and better know-how but gives more return of the investment.

Agricultural Diversification Using Bio-diversity: The bio-diversity in Nepal is considered one of the remarkable in the world. Within the short width of $200 \mathrm{Km}$ between the tundra weather of Tibetan plateau and Himalayan Mountain on north to hot and humid weather of Indian plane on south we have remarkable and unique biodiversity. Our long experience shows that the traditional agriculture products like paddy and wheat has become less and less cost effective and difficult for a competitive open market with India. Our ecological peculiarity can be used for diversified agriculture for growing typical and rare agricultural products. We can produce many special verities of - agricultural products, herbs, vegetables, horticulture and poultry that can be produced nowhere else. Although infrastructure like roads and electricity is necessary for any development model of Nepal the eco-agriculture model can flourish even under the existing infrastructure in most parts of the country. Researcher should identify such existing varieties of agri-products (animals, birds, fish and plants) that are typical and cultivated or such varieties of product that are of high medical/cash value but are getting difficulty in growing in other parts of the world. The current record shows that Nepal has about 6500 flowering plants 100 species of medicinal plants of which 246 are only found in Nepal. This list is assumed still longer. Further exploration on the list of varieties and their use is needed. The medicinal and aromatic plants database of Nepal includes 1,624 species of wild, domesticated, and naturalized plant species (FNCCI, 2008). Floriculture is also getting attention in the country.

Eco Tourism: Nepal has great potential for tourism. In the year 2008/09 about 510 thousand tourists arrived in the country generating Rs. 27960 million, which was $2.9 \%$ 
of the GDP. The most desired purposes for tourism were Mountaineering, Tracking, Pilgrimage, Rafting and Jungle Safari. New frontiers of adventurous tourism are also emerging such as- White Water Rafting, Paragliding, Ballooning, Rock climbing, Mountain biking in rough roads. Some tourists also arrive for study of the indigenous culture/ religion/ethnicity, medicinal plants, flora \& fauna, music \& dance. We need to develop village hubs like Ghandruk with modern health and communication facilities at several other potential areas.

Emphasis for Vocational Education: Vocational education is the development mantra of rural development. Rural people can directly relate such education with the local job markets. This will improve the potential of rural people. Researchers have shown the weak performance of traditional education and its high dropout rate. In year 2010, about 620 thousand adults have crossed the SLC appearing age of 15 years. However, in 2009 only $74 \%$ of such adults have appeared for SLC. According to SLC board 456719 appeared in SLC in 2066/67 of which about 42\% failed considering the regular and exempted result. This shows that about 162 thousand adults of this age have either failed or not appeared the traditional examination route. The dropout rate from primary level is still high. Such high escapee from education is mainly due to poverty (unaffordable education related cost) and the blink job future that an ordinary people having no linkage can visualize. Such youth are generally pushed for cheap labour. For such group of youth vocational education is the only better solution. Government should give more emphasis and investment for vocational education by regularly conducting trainings at various rural hubs. It should provide free training to the children of poor family.

\section{CONCLUSIONS}

As stated above the rural-urban discrepancy for major development indicators is very high and about $85 \%$ population dwell in rural area. These rural populations are less educated, access less to information, and lack market accessibility of for their agriculture or cottage industries products. The exclusion of rural sector in development efforts is a major bottleneck of poverty reduction and is thought to have strong links with many national problems, such as, international migration (brain drain), unplanned urbanization, current social unrest, and environmental degradation. We need to develop more and more rural hubs like Ghandruk, Jomsom, Namche, Lalbandi - as the center of rural life that provide them market, education, health services and entertainment. For this, the basic infrastructure such as road, electricity, vocational training centers, health post are to be developed in and between such hubs.

From the above discussion and analysis following are the summarized recommendations:

- Develop the rural infrastructure

- Prioritize the agro based industrial set-up 
* Agricultural should changed from traditional to eco-agriculture

- Develop tourism hubs at potential rural areas

- Develop market hubs in rural areas

* Prioritize the government educational fund for rural area and for vocational education

\section{References}

Central Bureau of Statistics (2003). Population Monograph of Nepal, Volume I and II

Central Bureau of Statistics (2005). Poverty Trends in Nepal

Central Bureau of Statistics (2006). Nepal Living Standard Survey (NLSS) 2005-06

Central Bureau of Statistics (2008).Nepal Labour Force Survey (NLFS)

Central Bureau of Statistics (2009). Statistical Year Book Nepal

Das T., Shrestha, D. L., Satyal, V.R. and Bajracharya, R. (2010). Upgraded Nepal Macroeconomic Model, ADB/NRB

Federation of Nepal Chamber of Commerce \& Industry (2009). Nepal and the World: A Statistical Profile

Government of Nepal (2010). Nepal Economic Survey, Ministry of Finance Medicinal Plant

Project, Dabar Group, Nepal Website: www.dabar.com Plants of Nepal, Vegetation Types and

Habitats of Nepal (2010), http://www.rbge.org.uk/science/ major-floras/flora-of-nepal

Sharma, S. Katiwada Y.R. and Satyal, V. R. (2006). Explaining Growth in Nepal, Explaining Growth in South Asia, Oxford University Press

United Nations Development Program (2004). Nepal Human Development Report 
Table A2: Economically active population in different census

\begin{tabular}{|l|r|r|r|r|}
\hline & \multicolumn{4}{|c|}{ Census year } \\
\hline & 1971 & 1981 & 1991 & 2001 \\
\hline Eco active population in agriculture & 4579327 & 6259654 & 5452404 & 6340861 \\
\hline \% of total active population & 94.37 & 91.37 & 81.1 & 59.61 \\
\hline \%male & 92.08 & 88.89 & 74.75 & 53.38 \\
\hline \%female & 98.17 & 96.06 & 90.46 & 67.74 \\
\hline \%Rural & & & & 65.58 \\
\hline \%Urban & & & & 38.16 \\
\hline \%mountain & & & & 78.48 \\
\hline \%hill & & & & 65.91 \\
\hline \%terai & & & & 49.15 \\
\hline
\end{tabular}

Source: Population Monograph, 2003

Table A3: Distribution of employed by main sector of employment

\begin{tabular}{|l|c|c|c|}
\hline & Agriculture & Non agriculture & Total \\
\hline Nepal & 71.1 & 28.9 & 100 \\
\hline Male & 65.1 & 34.9 & $\mathbf{1 0 0}$ \\
\hline Female & 76.6 & 23.4 & $\mathbf{1 0 0}$ \\
\hline Rural & 77.3 & 22.7 & $\mathbf{1 0 0}$ \\
\hline Urban & 30.8 & 69.2 & $\mathbf{1 0 0}$ \\
\hline Mountain & 84.1 & 15.9 & $\mathbf{1 0 0}$ \\
\hline Hill & 70.0 & 30 & $\mathbf{1 0 0}$ \\
\hline Terai & 70.0 & 30 & $\mathbf{1 0 0}$ \\
\hline Consumption quintile & & & \\
\hline Poorest & 80.7 & 19.3 & $\mathbf{1 0 0}$ \\
\hline Second & 77.3 & 22.7 & $\mathbf{1 0 0}$ \\
\hline Third & 76.7 & 23.3 & $\mathbf{1 0 0}$ \\
\hline Forth & 10.3 & 89.7 & $\mathbf{1 0 0}$ \\
\hline Richest & 49.5 & 50.5 & $\mathbf{1 0 0}$ \\
\hline
\end{tabular}

Source: NLSS 2004, CBS 
Table A4: Poverty Measurement by Employment Sector

\begin{tabular}{|l|c|c|c|c|c|c|c|c|c|}
\hline & \multicolumn{2}{|c|}{ Poverty Head count Rate } & \multicolumn{3}{|c|}{ Distribution of Poor } & \multicolumn{3}{|c|}{ Distribution of Population } \\
\hline & $1995 / 96$ & $2003 / 04$ & $\begin{array}{c}\text { Change } \\
\%\end{array}$ & $1995 / 96$ & $2003 / 04$ & $\begin{array}{c}\text { Change } \\
\%\end{array}$ & $1995 / 96$ & $2003 / 04$ & $\begin{array}{c}\text { Change } \\
\%\end{array}$ \\
\hline $\begin{array}{l}\text { Self } \\
\text { employed: } \\
\text { Agriculture }\end{array}$ & 43.1 & 32.9 & -24 & 60.7 & 66.9 & 10 & 58.8 & 62.7 & 7 \\
\hline $\begin{array}{l}\text { Wage earner } \\
\text { Agriculture }\end{array}$ & 55.9 & 53.8 & -4 & 15.7 & 10.9 & -31 & 11.7 & 6.2 & -47 \\
\hline Nepal & 41.8 & 30.8 & -26 & 100 & 100 & - & 100 & 100 & - \\
\hline
\end{tabular}

Source: (Table 1.4.1 p-16, Poverty Trends in Nepal, CBS, 2005)

Table A5: Predicted Value of GDP and Labour Force in 2020

\begin{tabular}{|l|r|r|r|}
\hline \multicolumn{1}{|c|}{ Indicators } & \multicolumn{2}{c|}{ Year } & $\begin{array}{c}\text { Average growth rate } \\
\text { (2000-09)* }\end{array}$ \\
\hline & 2009 & 2020 & 1.1170 \\
\hline Total GDP (Rs million) & 991316 & 3589866 & 1.0870 \\
\hline Agriculture GDP (Rs million) & 301567 & 844770 & 1.3352 \\
\hline Share of agriculture GDP & 30.4 & 23.5 & 1.0172 \\
\hline Total labour force & 12004 & 14489 & 1.0191 \\
\hline Agriculture labour force & 8870 & 10911 & 0.8860 \\
\hline Share of economically active population & 59.61 & 20.1 & 1.0398 \\
\hline Number of unemployed(in '000)** & 253 & 404.13 & \\
\hline
\end{tabular}

* Rate used for extrapolation for year 2020 ** For 2009, based on Table 9.0, NLFS 2008.

Table A6: Correlogram of Residuals from Regression of R_GDP on R_EMP, R_INVEST

Sample: 19762009

Included observations: 34

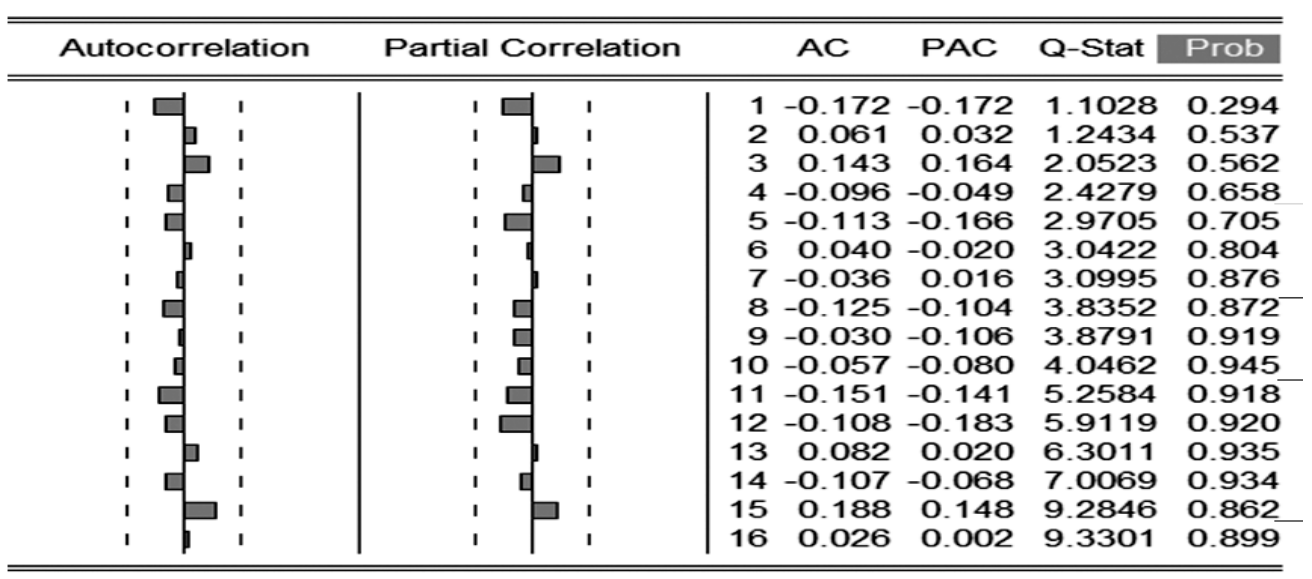

